\title{
Globalisation of missions: An exegesis on the Great Commission (Mt 28:18-20)
}

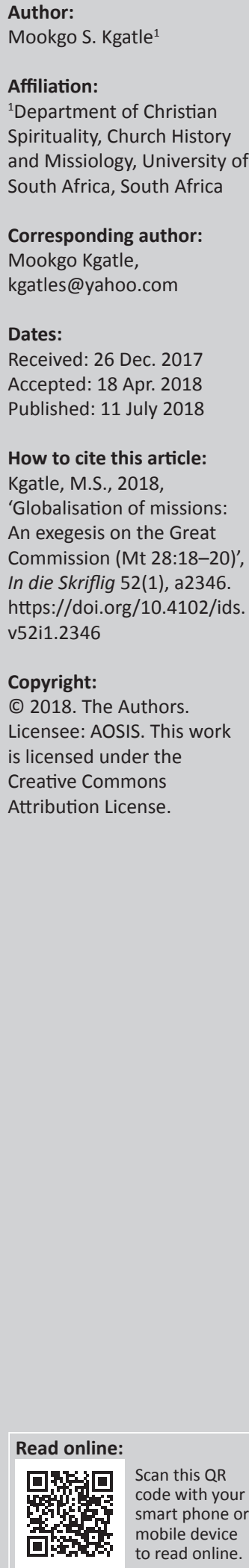

\begin{abstract}
This article is an exegesis on the Great Commission in Matthew 28:18-20 by using a grammatical historical approach. A grammatical historical approach on Matthew 28:18-20 demonstrates that Jesus' authority in heaven and on earth is a global authority. Furthermore, the commissioning of Jesus' disciples to go and make disciples of all nations, baptise them in the name of the Father the Son and the Holy Spirit and teach them to observe all things that Jesus has commanded them, is a call to global mission. When Jesus promised the disciples that he would be always with them, he assured them of a global victory. This will be achieved by looking at the history of interpretation of Matthew 28:18-20. The exegesis of this passage is explored in detail. The conclusion is that the Great Commission in Matthew 28:18-20 is a call to global mission.
\end{abstract}

\section{Introduction}

The Great Commission ${ }^{1}$ in Matthew 28:18-20² is an instruction to Jesus' disciples to make disciples of all nations, baptise and teach them to observe all things that Jesus has taught them. Jesus promises that he will be with them until the end. There is an enormous volume of literature in many languages dealing with the Great Commission: thousands of books, monographs, essays and articles. Every year some 10000 new bibliographical items on evangelisation are added. The vast majority expounds and analyses the subject from the standpoint of normative Christian theology: what the Bible says, what Christian mission requires and how it should be implemented in short, what Christians ought to do about it and how Christians ought to obey Christ's Great Commission in 28:18-20 (Fanning 2011:1). What is new in this article, is that the exegesis of the text helps us to arrive at the conclusion that this passage is about global missions.

The article will demonstrate through a grammatical historical approach that Jesus' authority in heaven and on earth is a global authority. Furthermore, the commissioning of Jesus' disciples to go and make disciples of all the nations, baptise them in the name of the Father, the Son and the Holy Spirit and teach them to observe all things that Jesus has commanded them, is a call to global mission. Lastly, when Jesus promised the disciples that he will always be with them, he assured them of a global victory. This will be achieved by looking at the history of interpretation and the exegesis of 28:16-20. The conclusion here is that the Great Commission in this passage is a call to global missions.

This article discusses the major themes. Jesus says that all authority in heaven and on earth is given to him. The word authority will be analysed to understand what kind of authority is Jesus talking about here and why was it important for him to talk about authority before the commissioning of the disciples. The article explores the meaning of teaching that Jesus has already commanded and the fact that Jesus promised to be always with them until the end.

\section{The theological context of Matthew 28:18-20}

The Great Commission in 28:18-20 is about the commandment that Jesus gave to his disciples to make disciples of all nations and teach them all things that Jesus has commanded. According to Chung (2015:276) this passage plays a crucial role as a motif in almost every Christian gathering, causing people to recall the significance of mission and evangelism. In fact, this passage functions as a support - even a command - allowing Christians to legitimise almost every kind of missionary work in order to compel non-Christians to become disciples of Jesus. In many cases throughout

1.In Christianity, the Great Commission is the instruction of the resurrected Jesus Christ to his disciples to spread his teachings to all the nations of the world. The most famous version of the Great Commission is in Matthew 28:18-20, where on a mountain in Galilee Jesus calls on his followers to baptise all nations in the name of the Father, the Son and the Holy Spirit.

2.All further references to Matthew 28:18-20 will be indicated only by chapter or verses or refer to as 'this passage' 
the history of mission, Christians, in general, and missionaries, in particular, have focused on the task of fulfilling the commission as worded to Jesus' disciples without serious consideration for how the commission is carried out in a given space and time.

It has been recognised by Finkbeiner (1991:16) that the closing pericope (28:18-20) is fully intended to be the climax towards which the entire gospel moves. By tying together some of Matthew's most dominant themes, these verses give them a new depth that reaches back and sheds light on the entire gospel. Matthew's Gospel ends with the expectation of continued mission and teaching. The five preceding sections always conclude with a block of Jesus' teaching (Mt 3:1-26:5), but the passion and resurrection of Jesus ends with a commission to his disciples to carry on with that same ministry in the light of the cross, the empty tomb, and the triumphant vindication and exaltation of the risen Lord.

Matthew 28:18-20 is a charge given by Jesus to his disciples in order that they may continually reproduce themselves for as long as Christ desires. Matthew uses five lines to present this scenario. He first covers the characters and setting, then he moves on to the circumstances. He gives them motivation for their action, commands them what to do and how to do it, and finally, closes with a promise that only God can make (Phelps 2011:17). Jesus therefore commissions the disciples to go out and make disciples of all the nations by creating communities of obedience among the nations. 'Mission is replicated discipleship, learned through ethical obedience and passed on through teaching' (White \& Assimeng 2017:5).

This passage is an adequate model for a church missions programme in setting a vision, establishing purpose and making decisions. It asserts that the model of making disciples can integrate the inseparable entities of evangelism and social justice in the mission of the church, while at the same time, respecting the distinction between them. While social justice is never misplaced in Christian mission, it can never replace the proclamation of the gospel (Stromsmoe 2011:6). The Great Commission is a charge to proclaim the gospel which involves preaching the good news, witnessing from a personal experience and relationship with God, effectively loving one's neighbour by the power of the Holy Spirit, and journeying through the process of discipleship and growth into becoming a church (Jambrek 2016:155).

Matthew 28:18-20 must be viewed as the gospel's climax, but over and above this, it needs to be appreciated that it looks more towards the future than back to the past. It is in other words, a bridging passage that concludes Matthew's story of the 'historical Jesus' and points the reader to a new era of universal mission for the church which conducts its endeavours under the protection of the risen Christ (Sim 2014:2). This passage is a careful summary of the key themes of the gospel which tie together Matthew's Christology, ecclesiology and salvation history (Donaldson 1985:170). Matthew 28:18-20 not only concludes the resurrection narrative and the book of Matthew as a whole, but also summarises the message of the first gospel itself. The heading, Great Commission, is inappropriate, because the passage is mainly an epiphany or exaltation story directed to the new status of the risen One (Osborne 1976:73).

Witherington (2006:531) argues that, while the Great Commission reiterates some of the gospel's major themes and draws together a number of threads in the text, it cannot really be called the key to the interpretation of Matthew. France (2007:1108-1109) concedes that it is possible to read the texts theologically from the Great Commission to illuminate earlier parts of the gospel, but he argues that, both in literary terms and aesthetically, it is preferable to read the story chronologically - from beginning to end - to appreciate the fully unfolding revelation of the Son of God which reaches its climax in the final pericope.

Nonetheless, the Great Commission is important in understanding the whole Gospel of Matthew. The Great Commission is Matthew's 'table of contents' located at the end. The beginning and the end are more significant than the other Gospels (Lee \& Viljoen 2010:1). Not only is 28:18-20 an integral part of the entire gospel, but indeed the evangelist intended it as a summary and an endorsement of the gospel. No other book in the entire scripture comes to such a satisfactory conclusion as Matthew does with Jesus' command to preserve his words and make disciples through baptism and his promise to be with the church until the current epoch has ended. ${ }^{3}$ The evangelist never informs his readers whether the apostles actually followed the command to make disciples of the Gentiles (Scaer 1991:246).

The history of interpretation of this passage demonstrates that many scholars (Donaldson 1985; Osborne 1976; Sim 2014) view the Great Commission as a summary. Although others (France 2007; Witherington 2006) argue against the Great Commission as a summary of the gospel, they at least acknowledge that it is a major theme of the gospel. What is important for this article is an exegesis of the text to understand the original meaning. Major Greek words and verbs will be analysed in order to understand the text. The purpose is to demonstrate that the call of Great Commission is a call to global missions.

\section{Exegesis of Matthew 28:18-20 All authority}

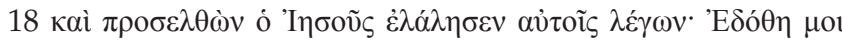

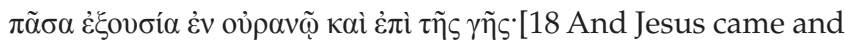
spoke to them, saying, 'All authority has been given to Me in heaven and on earth'.]

In this passage, the one who spoke the commission is the one who had been given 'all authority' (v. 18) to do so. The authority of Christ is not a new theme in this gospel (see e.g. Mt 7:29; 10:1, 7-8; 11:27; 22:43-44; 24:35). His power to defeat

3.Although this might be true, it must be noted that some scholars argue that the long ending of Mark's Gospel rivals Matthew's Gospel. Even if the long ending does not belong in Mark's Gospel, some contend for it. 
the devil (Mt 4:1-11), to teach like no other (7:28-29), to calm nature $(8: 23-27)$, to forgive $\sin (9: 1-8)$ and to heal the sick (9:27-31) had already been established (Lawless 2011:17). Authority refers to the power of deity assumed by him at his resurrection and ascension. Authority in this text is transferred to human beings, because, regarding his divine nature, 'all power' has been always his. On the other hand, it may simply be an assertion of his 'eternal power and Godhead' as 'Son of Man'. It was to prepare the disciples to expect his power to be with them in their difficulties and weakness as they were to make disciples of the nations (Culver 1968:117).

Despite (or perhaps because of) the hesitation of the eleven, Jesus approaches them. Before the commission in verse 19, he assures them of his sovereignty over heaven and earth. Elsewhere in Matthew Jesus claims the authority to forgive sins (9:6) and that all things have been given to him by the Father (11:27). Therefore, the claim here only heightens the reader's understanding of Jesus' authority. Jesus gives a new dimension to the implications of his authority (Freeman 1997:16).

Christ addresses his disciples - some of whom are hesitant to worship him - and clearly expresses his exalted position of authority. Matthew 28:18b expresses Jesus' consciousness of full authority with a view to wielding that authority in the command that follows (Chung 2015:283). 'Jesus claims universal authority. It is on the basis of this mediatorial authority, in heaven and on earth, that the Saviour issues his commission to his followers' (Thomas 2000:44). Just as Jesus counted on the authority of his Father to control the circumstances and resources to enable him to carry out his mission, he expects his disciples to count on his authority to fulfil and obey all his commands as he did in obedience to the Father's will. The declaration means that he will exercise his full 'authority in heaven and earth' in order to accomplish his purpose in the world and in and through their lives (Fanning 2011:5).

The indicative statement that introduces the Great Commission ('all authority in heaven and on earth has been given to me') alerts us to the reality that Jesus is not only a teacher - he is the Lord. This reinforces the conclusion that the pattern of disciple making is not to be a human relationship, but one that faithfully points to Christ. In other words, we do not make disciples that follow us, but rather, with God's grace and help, we make disciples that follow Jesus (Stromsmoe 2011:37). Jesus indicates that the resurrection was his enthronement, the beginning of his kingly reign, when he says, 'All authority in heaven and on earth has been given to me'. Authority, indicating Matthew's Christological theme, is translated from the Greek word $\dot{\varepsilon} \xi o v \sigma i ́ \alpha$ [right or power]. By proclaiming himself as the highest and only authority, Jesus himself stands behind the command of verse 19 (Hertig 2001:345).

The immediate literary context of the command to make disciples is the risen Jesus' claim of authority over heaven and earth. The command to make disciples is closely related to the claim of authority through the use of the conjunction oṽ $v^{4}$ (Lee \& Viljoen 2010:4). The gospel points to Jesus as the final, ultimate and complete revelation of God, but this arrangement is then punctuated by Jesus' own words: 'All authority is given to Me in heaven and earth'. This passage can, with good reason, refer to Jesus in almost Pauline terms as the one in whom heaven and earth have their completion the new Adam in which God establishes his new creation (Col 1:15-16). God establishes Christ as the new Adam, the man from heaven (1 Cor 15:45) in whom his new humanity is joined together - not by blood, but by the proclamation of the gospel, baptism and faith (Scaer 1991:253).

In verse 18 , Jesus is a man with authority. He received this authority from God the Father and in this passage Jesus is transferring the power to his disciples so that they can fulfil the Great Commission. This authority, according to Jesus, precedes the Great Commission, because the process of making disciples of all nations is a divine assignment that the disciples cannot fulfil by their own power. What is more important for this article is that this authority is given in heaven and on earth. It is a universal authority. Jesus is assuring his disciples that there is no other power in heaven or on earth than the power that the Father has given him.

\section{All nations}

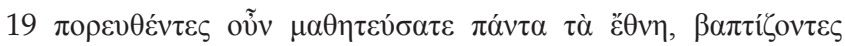

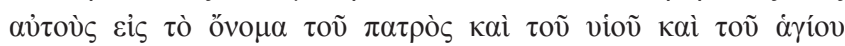
$\pi v \varepsilon v ́ \mu \alpha \tau$, [19a Go therefore (oṽv) and make disciples of all the nations, baptising them in the name of the Father and of the Son and of the Holy Spirit,]

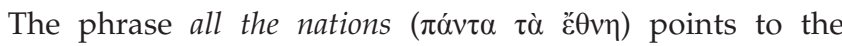
unrestricted nature of mission. The Great Commission's

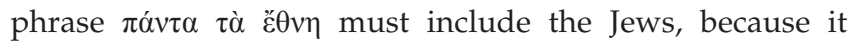
includes the qualifying adjective $\pi \dot{\alpha} v \tau \alpha$ [all] as narrative of the sheep and goats. In fact, mission to the Jews had already been commanded (Mt 10:6) and is now taken for granted (25:32). Furthermore, it would be absurd to imagine that a mission mandate given from a Jew to Jewish disciples would exclude Jews, especially when they have already been included (Mt 10:6; Hertig 2001:347).

Some understand the term $\check{\theta} \theta v \eta$ as referring only to Gentiles an interpretation likely built on a belief that God had ultimately rejected the Jews who had first rejected him (Lawless 2011:19). Others view 'nations' as 'peoples' or 'ethnic groups'. Gentiles and Jews alike would thus have been included in this call. The gospel would be for all the world - not only for the lost sheep of Israel (Mt 10:6; Lawless 2011:19). The word nations translates the word $\ddot{\varepsilon} \theta v \eta$ from which we have the English word ethnic. Today we use the expression ethnic people group to define the many ethnolinguistic distinct groups of people that consider themselves

4.oviv is apparenty a primary word (adverbially) certainly or (conjunctionally) accordingly and (so, truly), but, now (then), so (likewise then), then, therefore, verily, wherefore. It is a conjunction indicating that something necessarily follows verily, wherefore. It is a conjunction indicating that something necessarily follows
from another. It is used in drawing a conclusion and in logically connecting sentences together (see Mounce \& Mounce 2008). 
different from other people because of their unique language, culture and beliefs. Churches today largely ignore or are ignorant of these groups of people. Most prayer lists in churches never include the names of any unreached group of people (Fanning 2011:12).

Most scholars, according to Sim (2014:3), accept the view that

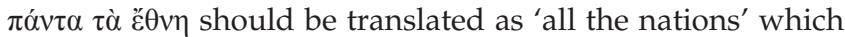
includes both the Jews and the Gentiles. On this reading of the text, the original mission to the Jews is now expanded to include the Gentiles. It emphasises the importance of Jesus' focus on all nations. This marks a shift from Jesus as a Jewish rabbi to Jesus as the way to redeem the entire world. If the disciples can change the people of all nations, the world can be redeemed (Hiebert 1992:343).

Viljoen (2006:259) says that the horizon of Matthew is broadened to include Gentiles along with Jews. The Matthean community welcomed and expected converts from all nations. This created much tension with the synagogue where Jews strived to uphold their exclusiveness within a community that was overwhelmed by Hellenism. Through the continuing challenge of the Great Commission, people from all nations are to be made Christ's disciples (Lee \& Viljoen 2010:3). Each geographic and cultural context needs to be considered, because 'the first divine act of translation into humanity gives rise to a constant succession of new translations'.

Franklin and Niemandt (2013:4) say that the target of the mission charge of the Great Commission is 'all nations'.

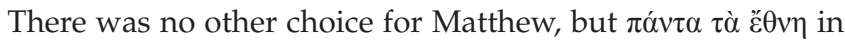
order to convey the idea that the commission was aimed at all human beings, including Jews. Translating the phrase as 'all the Gentiles' and thereby excluding the Jews from its connotation does not coincide with the risen Lord's claim of universal authority. The word study favours the translation of the phrase as 'all nations' rather than 'the entire Gentiles'.

What is important and even shocking for Matthew's Jewish audience is that the new followers of Jesus are to come from the Gentiles and that they, the descendants of the patriarchs, have lost their special status (Mt 8:11-12). Jesus had given command to his disciples to go to the lost sheep of the house of Israel and to avoid the Gentiles (Mt 10:56). In sharp distinction to this prohibition is verse 19 where the Jews, as a distinct people, are not even mentioned. Disciples are to be made of the Gentiles. No longer is the mission only to the Jews, or first to the Jews and then to the Greeks (Rm 1:16; Gl 3:28), but simply to the Gentiles. It is noteworthy that ethnic is a neuter plural, and would thus be expected as the proper form in opposition to it (Scaer 1991:251).

Therefore, it is better to take the commission here as expanding the 'mission' of Matthew 10:5 to include all ethnic groups. What Matthew intends with this reading, is that the disciples understand that their mission is to ethnic groups and they must preserve the ethnic identity of each group. Group conversions can, and perhaps should be the norm. Thus, Jesus commands the making of disciples of individuals from all ethnic groups, including Judaism (Freeman 1997:18). The mandate is that Christians have to proclaim the good news to all nations and thus fulfil the commission given by Christ in verse 19 (Tucker \& Woodbridge 2012:2).

Jesus commissioned the disciples to a worldwide mission of teaching which was parallel and in contrast to Rome's desire for worldwide societal control (Cronshaw 2016:111). In this way of thinking, the Trinity, which is the centrality of the Christological identity in Christian doctrine, is marginalised by the beneficial work of the Son for human beings on earth, just as the centrality of the power relation between different groups of people is relativised by the welfare of all human beings. This benefit of welfare would then explain why the mission command contains an injunction to baptise all nations and to bring new believers in through a confirmation of the triune God working cohesively (Chung 2015:286).

The Great Commission is a commission to all nations as

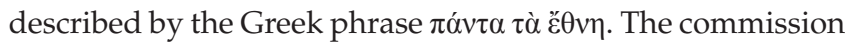
now includes the Gentiles as opposed to the previous whereby the disciples were commanded to only go to the lost sheep of the children of Israel. It is a commission to all people regardless of race, religion, colour and class. The gospel now must be preached to the whole lost world. The gospel has expanded to other ethnic groups - not only to the Jews. The Great Commission includes all the geographic and cultural contexts of the world.

\section{All things that I have commanded you}

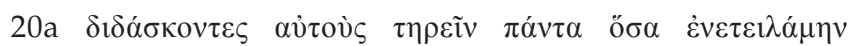
$\dot{v} \mu \mathrm{i} v \cdot[20$ a teaching them to observe all things that I have commanded you].

The command is to 'teach all things', and the author records Jesus giving a command for active evangelism somewhere in those discourses. Then the command would apply to believers at all times and in all places because of Christ's command in Matthew 28 (Phelps 2011:33). The final phrase of the Great Commission, 'teaching them to obey everything that I have commanded', refers to the on-going training in all the commands of the New Testament. The phrase to obey means 'to attend to carefully, or to guard a prisoner'. It refers to a lifestyle of learning, remembering and practising all the teaching commands of Jesus and the Holy Spirit throughout the New Testament (Fanning 2011:17).

'Teaching them to obey everything I have commanded you' provides the content of what is to be passed on to others in the process of discipleship. If the disciples are to teach them to obey 'everything' Jesus has commanded, then the mission of the disciples is to be holistic (Hertig 2001:348). Discipleship involves diligent teaching of the gospel and practices that promotes a lifestyle of becoming ever more like Jesus Christ. Discipleship is not limited to what you can comprehend - it must transcend all comprehension. It is a life of strict 
adherence and obedience to Christ and his commandments. It is also a strict adherence to Christ as the object of our faith (White \& Assimeng 2017:6).

The 'teaching' of verse 20 refers to the communication of the total revelation which God has given in Jesus and not only the call to faith. The call to repentance (i.e. contrition and faith) is the call to be baptised. The teaching ( $\delta 1 \delta \alpha$ ó goes beyond that call. This teaching does not refer to that necessary preaching which must precede baptism, and in a sense, is comprehended by baptism, but rather to the continued exposition of the gospel in the church among those who have become disciples through baptism. Those who are made disciples remain disciples by listening to the apostolic teaching which is nothing else than preaching the complete counsel of God (Scaer 1991:256).

The disciples are commissioned to teach the new disciples to keep what Jesus commanded. It is Jesus' own teaching and not the Torah that is the substance of what is to be taught. Throughout Matthew, the emphasis has been on Jesus as the teacher. Now the disciples are for the first time commissioned to also teach. However, it is not just that they are to teach. They are to teach the converts 'to keep' ( taught. This verb adds a distinctively ethical dimension to the teaching. Christianity is Torah-based, but it is, nevertheless, inherently moral. Any proclamation of the gospel, which does not have this Christocentric ethic, is not the gospel as Matthew presents it (Freeman 1997:18).

The disciples are commanded to baptise those who believe and after the baptism to orientate the believers in the way that they should live here on earth as the children of God. This commandment is based on the whole gospel of Jesus without selecting some facts. It means the gospel of Jesus, as presented in the Great Commission, is a holistic gospel. It has an ability to cover various areas of life as Jesus taught his disciples. The Great Commission is a command to teach the believers the whole truth without compromise; it is teaching without fear and favour.

\section{I am with you always}

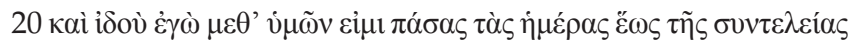

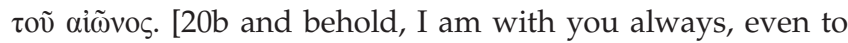
the end of the age. Amen].

The promise of Jesus at the end of Matthew, 'I am with you always, even to the end of the ages' (v. 20), was much more than a perfunctory closing to a call statement. It was an announcement of victory even in the midst of persecution. In all of these dangerous situations, the disciples would need to trust the bookend truths of Matthew's Gospel: the virginborn redeemer, named 'God with us' (1:27) would be with them to the end (28:20; Lawless 2011:23).

This last promise in Matthew extends beyond the life span of the disciples to every believer that commits to the task of raising up a group of Christ-followers among every ethno-linguistic group of people on earth to the end of the age' (v. 20b). This phrase is also found in Matthew 13:39-40, 49; $24: 3$ which refers to the end of the present age when the Son of Man returns to establish his kingdom. Thus, the promise not only applied to these first century disciples, but to every disciple since then and until the end of the church age (Fanning 2011:21).

The Great Commission, with the task of proclaiming the gospel and making, baptising and teaching the disciples along with serving the needy, cannot be separated from the power and the presence of the risen Lord, Jesus Christ. Christ has promised to be with those who will fulfil his commission in all the days to the end of the world (Jambrek 2016:158). The promise of Jesus to be present 'always, to the very end of the age' indicates that his presence and mission is extended to the end of human history. Therefore, the Great Commission is an eschatological mandate given in a period between the resurrection and the end of human history (cf. Mt 24:14; Hertig 2001:348).

The commission ends with the promise of Jesus' presence which is similar to those Old Testament passages in which God promised his presence to those he commissioned. Now they are promised that he will be with them all the days until the consummation of the ages. In Matthew 1:23 the name Immanuel was interpreted as 'God (is) with us'. Now the disciples are assured that, as they go in his name, he will continue to be Immanuel to them.

The Great Commission ends with the promise that Jesus will be with his disciples until the end of the ages. Jesus is assuring his disciples that the fact that he is ascending to heaven to be at the right hand of his Father does not mean he is leaving them. It is not only the promise to the disciples, but also to the believers that will be born in the time to come. The Great Commission is timeless and infinite, because it is to be valid until the end of the ages. It is a commission beyond human history.

\section{Globalisation of mission}

Before mission is globalised there is a need to localise it. Mission cannot be globally powerful if it is not locally relevant. Therefore, globalisation of mission involves four distinct qualities: Firstly, the creation of new and multiplication of existing social networks and activities that increasingly overcome traditional political, economic, cultural and geographical boundaries. Secondly, globalisation involves the expansion and stretching of social relations, activities and interdependence. Thirdly, globalisation involves the intensification and acceleration of social exchanges and activities. Lastly, globalisation involves the subjective plane of human consciousness (Johnson 2010:165).

It was through the modern missionary movement that Christianity became a worldwide phenomenon, and in that 
process, Christianity came to acquire the image of a western religion. The subsequent globalisation of the image of western Christianity poses a problem for non-western Christianity. Although we talk about a post-Christian West and a post-western Christianity, the prevailing forms of Christianity in most parts of the non-western world are still dominated by western influences (Johnson \& Ross 2009:104). This is wrong, because Christian mission is not about the promotion of one culture, but the extension of the global kingdom of God.

The Great Commission in $28: 18-20$ is a global mission, because in it, Jesus speaks about the authority in heaven and on earth. Jesus is not only the teacher of the word, but he is Lord. Jesus has universal authority that he received from his father which he then transfers to his disciples. This authority also speaks volume to the defeat of the devil and his demonic forces. Jesus has authority over sicknesses, sin and other ailments. After his resurrection, Jesus has authority over death. It means that no power can hinder the propagation of the gospel. Jesus is assuring his disciples that no demon in hell can stop them from preaching the gospel.

The Great Commission in this passage is a global mission, because Jesus' disciples are called to make disciples of all nations. Mission is not restricted to a particular nation, but is inclusive of all nations, including the Jews and the Gentiles. The gospel is supposed to spread to all people of all ages, race, religion, colour, class, et cetera. The gospel should reach all ethnic groups of people in the world in their different languages, culture and beliefs. The gospel should spread to each geographic context of the globe. It is a worldwide mission.

The Great Commission in this passage calls the disciples to baptise the believer and teach them all that Jesus has commanded them to teach. It is a holistic mission. Christians in a global mission should not pick and choose what to preach, but should preach without compromise. The message of the gospel does not change because of different contexts. There is nothing like an African gospel. However, there is a gospel in an African context. The Great Commission extends the time beyond human history. It also means that the gospel transcends the present age. An eschatological reality goes beyond human history. Moreover, Jesus assures his disciples about his eternal presence and eternal victory.

In summary, the Great Commission fulfils the four distinct qualities of globalisation outlined by Johnson (2010:165-169). Jesus was asking his disciples to create new and multiply mission activities that increasingly overcome traditional political, economic, cultural and geographical boundaries. Jesus commanded the disciples to expand and stretch social relations, activities and interdependence. Jesus, in the Great Commission, intensified and accelerated social exchanges and activities that goes beyond human history into eternity.

\section{Conclusion}

The exegesis on the Great Commission in 28:16-20 has helped us to arrive at the following conclusions. Jesus' authority in heaven and on earth is a global authority. The commissioning of Jesus' disciples to go and make disciples of all the nations, baptise them in the name of the Father, the Son and the Holy Spirit, and teach them to observe all things that Jesus has commanded them, is a call to global mission. Lastly, when Jesus promised the disciples that he will always be with them, he assured them of a global victory. The main conclusion here is that the Great Commission in this passage is a call to global missions.

\section{Acknowledgements Competing interests}

The author declare that he has no financial or personal relationships which may have inappropriately influenced him in writing this article.

\section{References}

Chung, Y., 2015, 'A postcolonial reading of the Great Commission (Matt 28:16-20) with a Korean myth', Theology Today 72(3), 276-288. https://doi.org/10.1177/ 0040573615601466

Cronshaw, D., 2016, 'A Commission "Great" for whom? Postcolonial contrapunta readings of Matthew 28:18-20 and the irony of William Carey', Transformation 33(2), 110-123. https://doi.org/10.1177/0265378815595248

Culver, R.D., 1968, 'What is the church's Commission? Some exegetical issues in Matthew 28:16-20', Bibliotheca Sacra 125(499), 239-253.

Donaldson, T.L., 1985, Jesus on the mountain: A study in Matthean theology, JSOT Press, Sheffield, UK.

Fanning, D., 2011, 'The Great Commission', Journal of Liberty Baptist Theological Seminary 1(1), 1-20.

Finkbeiner, D., 1991, 'An Examination of "Make Disciples of All Nations" in Matthew 28:18-20', Calvary Baptist Theological Journal 7(1), 12-42.

France, R.T., 2007, The Gospel of Matthew, Eerdmans, Grand Rapids, MI.

Franklin, K.J. \& Niemandt, C.J.P., 2013, 'Vision 2025 and the Bible translation movement', HTS Teologiese Studies/Theological Studies 69(1), Art. \#1332, 8 pages. https://doi.org/10.4102/hts.v69i1.1332

Freeman, H., 1997, 'The Great Commission and the New Testament: An exegesis of Matthew 28:16-20', Southern Baptist Journal of Theology 1(4), 14-23.

Hertig, P., 2001, 'The Great Commission revisited: The role of God's reign in disciple making', Missiology 29(3), 343-353.

Hiebert, D.E., 1992, 'An expository study of Matthew 28:16-20', Bibliotheca Sacra 149, 338-354.

Jambrek, S., 2016, 'The Great Commission in the context of the Evangelical Churches of Croatia in the second part of the twentieth century', Kairos: Evangelical Journal of Theology 2(2), 153-179.

Johnson, T.M., 2010, 'Globalization, Christian identity and frontier missions', International Journal of Frontier Missiology 27(4), 165-169.

Johnson, T.M. \& Ross, K.R., 2009, Atlas of global Christianity, University Press, Edinburgh.

Lawless, C., 2011, 'To all the nations: The Great Commission passages in the Gospels and Acts', The Southern Baptist Journal of Theology 15(2), 16-26.

Lee, K. \& Viljoen, F.P., 2010, 'The target group of the Ultimate Commission (Matthew 28:19)', HTS Teologiese Studies/ Theological Studies 66(1), Art. \#184, 5 pages. https://doi.org/10.4102/hts.v66i1.184

Mounce, R.H. \& Mounce W.D. (eds.), 2008, Greek and English interlinear New Testament (NASB/NIV), Zondervan, Grand Rapids, MI.

Osborne, G.R., 1976, 'Redaction criticism and the Great Commission: A case study toward a biblical understanding of inerrancy', JETS 19(2), 73-85.

Phelps, R., 2011, The Great Commissioning: An exegesis of Matthew 28:16-20, Liberty University, Lynchburg, VA.

Scaer, D.P., 1991, 'The relation of Matthew 28: 16-20 to the rest of the Gospel', Concordia Theological Quarterly 55(44), 245-266.

Sim, D.C., 2014, 'Is Matthew 28:16-20 the summary of the Gospel?', HTS Teologiese Studies/Theological Studies 70(1), Art. \#2756, 7 pages. https://doi.org/10.4102/ hts.v70i1.2756 
Stromsmoe, L., 2011, 'Making disciples: A foundation for an integrated mission program', PhD dissertation, Reformed Theological Seminary, Virtual Campus.

Thomas, R.L., 2000, 'Historical criticism and the Great Commission', The Master's Seminary Journal 11(1), 39-52.

Tucker, T. \& Woodbridge, N., 2012, 'Motivational factors for a sports ministry: A case study of churches in Pretoria', HTS Theological Studies 68(2), \#Art. 1199, 7 pages.
Viljoen, F.P., 2006, 'The Matthean community according to the beginning of his Gospel', Acta Theologica 26(2), 242-262.

White, P. \& Assimeng, A.A., 2017, 'Televangelism: A study of the "Pentecost Hour" of the church of Pentecost', HTS Teologiese Studies/Theological Studies 72(3), a3337-1. https://doi.org/10.4102/hts.v72i3.3337-1

Witherington, B., 2006, Matthew, Smyth \& Helwys, Macon, GA. 